\title{
Single lever Hum- phrey A.D.E. low flow universal anaesthetic breathing system
}

David Humphrey MBBS (Lond.) DA (S.A.), John G. Brock-Utne

MA MB BCH (TCD) FFA (S.A.) MD (Bergen), John W. Downing MB BCH FFA (S.A.) FFARCS (Eng.)
Part I: Comparison with dual lever A.D.E., Magill and Bain systems in anaesthetized spontaneously breathing adults
The single lever Humphrey A.D.E. anaesthetic system, in both coaxial and parallel (non-coaxial) forms, has recently been introduced. In principle the system offers efficient "universal" function by combining the advantages of Mapleson A, D and E systems. A within-patient comparison of its function in the Mapleson A mode (lever up) in spontaneously-breathing anaesthetized subjects was made to that of the original two lever A.D.E., the Magill (Mapleson $A$ ) and the Bain (Mapleson D) systems. The coaxial and parallel single lever A.D.E. systems functioned identically to each other and to the original two lever A.D.E. system, a mean fresh gas flow (FGF) of $51 \mathrm{ml}$ $\mathrm{kg}^{-I} \cdot$ min $^{-1}$ causing minimal rebreathing. Under identical conditions, the mean $F G F$ required to just cause rebreathing increased to a mean of $71 \mathrm{ml} \cdot \mathrm{kg}^{-1} \cdot \mathrm{min}^{-1}$ and $150 \mathrm{ml}$ $\mathrm{kg}^{-1} \cdot \mathrm{min}^{-1}$ with the Magill and the Bain systems respectively. With the single lever system, the switch to its Mapleson $E$ mode for controlled ventilation involves the selection of the only alternative lever position (lever down) without further adjustment. The function and practical advantages in this $E$ mode are presented in Part II.

\section{Key words}

EQUIPMENT: ANAESTHETIC BREATHING SYSTEMS: Bain, Humphrey A.D.E., Magill, Mapleson; VENTILATION: spontaneous.

From the Faculty of Medicine, Departments of Anaesthetics and Physiology, University of Natal, PO Box 17039, 4013 Congella, Durban, South Africa, where correspondence should be addressed to Dr. Humphrcy.

Preliminary reports were presented at the 1985 South African Sociely of Anaesthetists Congress, Durban and at the 198518 th Scandinavian Society of Anaesthesiologists Congress, Iceland.
The search for an efficient multipurpose anaesthetic breathing system has intrigued anaesthetists for years. So much so that Nunn' commented:

Anaesthetists show astonishing ingenuity in "improving" gas circuits. While these often appear harmless, it sometimes proves that the effects are surprisingly complex and it may become almost impossible to determine the composition of the gas which the patient is inhaling. Control of the gaseous environment is essential for good anaesthesia, and the anaesthetist should know precisely what the patient is breathing at all times.

In the light of these remarks, two independent studies ${ }^{2,3}$ have been undertaken during spontaneous and controlled ventilation in anaesthetized patients to evaluate the function of the Humphrey A.D.E. system, ${ }^{4}$ a new multipurpose system claiming to combine the advantages of Mapleson A, D and E systems. The authors of both papers ${ }^{2,3}$ reported that the Humphrey A.D.E. system did indeed function

ABBREVIATIONS

A.D.E. = Humphrey A.D.E. anaesthetic breathing system

A.D.E. = A.D.E. set in A mode

A.D.E. = A.D.E. set in D mode

A.D.E. = A.D.E. set in E mode

FGF $=$ Fresh gas flow

$\mathrm{PICO}_{2}=$ Minimum inspired carbon dioxide tension

$\mathrm{PECO}_{2}=$ End-expired (or end-tidal) carbon dioxide tension 


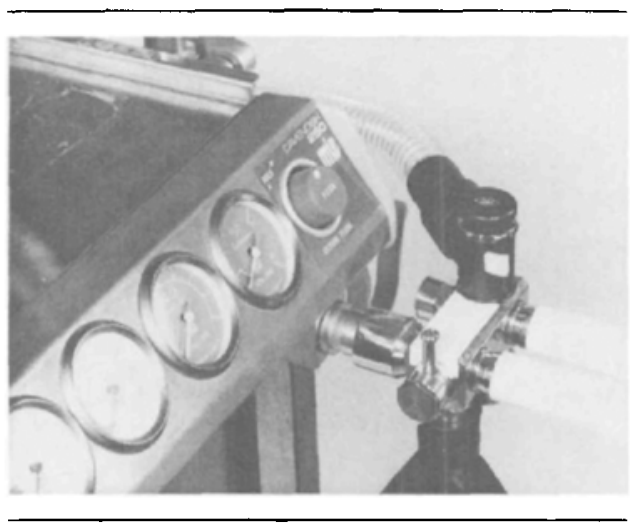

FIGURE 1 Photograph of the parallel version of the single lever Humphrey A.D.E system mounted on an andesthetic machine. Complete control is effected by positioning the lever upright for spontaneous respiration in the Mapleson A mode, and down for automatic controlled ventilation in the Mapleson E mode. Expired gases are collected at the exhaust valve or ventilator outlet, both away from the patient's face. A pressurelimiting device is fitted near the exhaust valve on the expiratory limb and is in circuit in both positions of the lever. as a "low flow universal system" functioning safely and efficiently for both spontaneous and controlled ventilation. Further, the validity of the original claim made by Humphrey ${ }^{4}$ was confirmed in that, for spontaneous respiration, the system required a significantly lower fresh gas flow (FGF) than the Magill system to prevent rebreathing of alveolar gas. The advantages of the Humphrey A.D.E. system have also been confirmed in routine clinical practice. $^{5}$

Both these independent studies ${ }^{2,3}$ were conducted on the original "dual lever" Humphrey A.D.E. system. ${ }^{4}$ However, a new single lever version ${ }^{6}$ has been designed which further facilitates the interchange between the various modes of use (Figures 1-3). In a similar manner to the dual lever system, this single lever is positioned up in the Mapleson A mode for spontaneous respiration and down in the Mapleson $\mathrm{E}$ mode for controlled ventilation. This new version is also available both as a parallel (non-coaxial) (Figures 1,2) and a coaxial system (Figure 3).
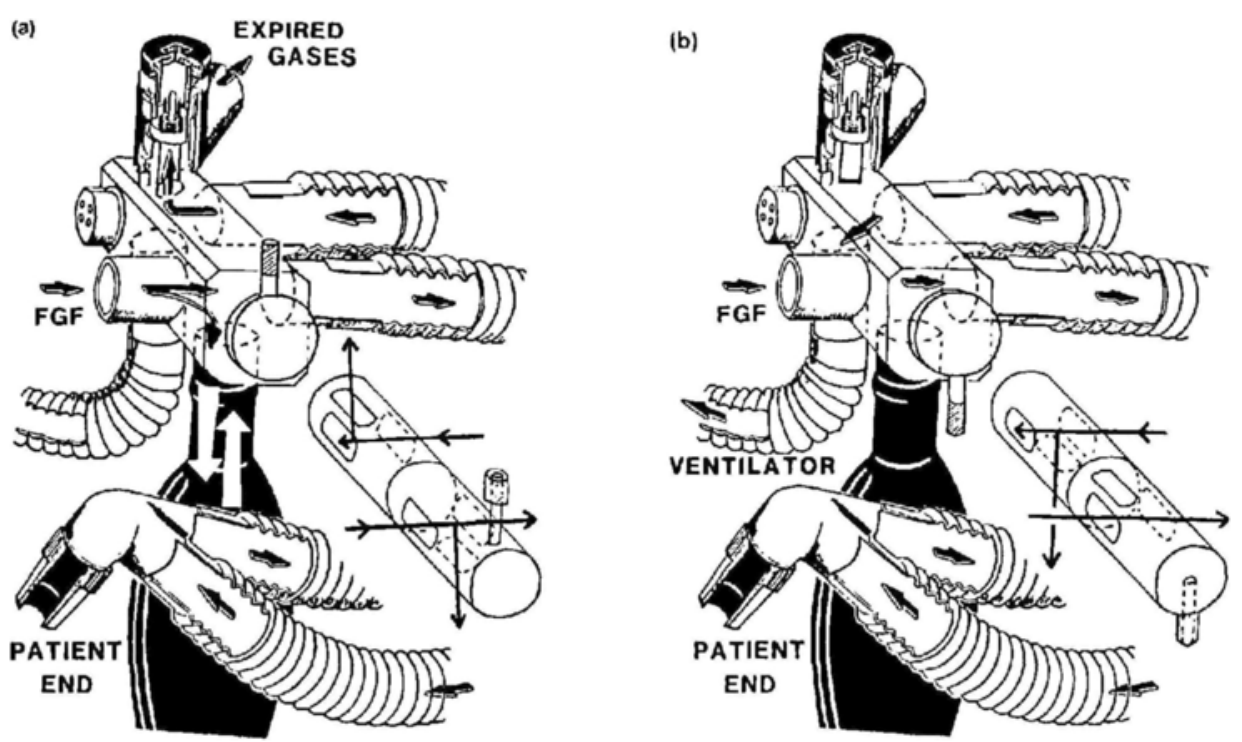

FIGURE 2 Diagram of the parallel (non-coaxial) single lcver Humphrey A.D.E. system with an exploded view of the cylinder mechanism. The lever controls a single rotating cylinder which passes through both inspiratory and expiratory limbs. There is no gaseous connection between these limbs. (a) When the lever is upright ( $A$ mode) the inspiratory reservoir bag and expiratory valve are in circuit, while the ventilator is excluded. Alveolar gases are exhausted and scavenged at the exhaust valve. (b) When the lever is down (E mode), the ventilator is now included with the exclusion of the reservoir bag and exhaust valve. The system is simply two tubes, as is the Bain circuit during controlled ventilation. The pressure-limiting device stays in cireuit in either mode. 22 or $15 \mathrm{~mm}$ internal diameter tubing may be used. FGF $=$ fresh gas flow. (Reproduced from Humphrey, ${ }^{6}$ with permission.) 

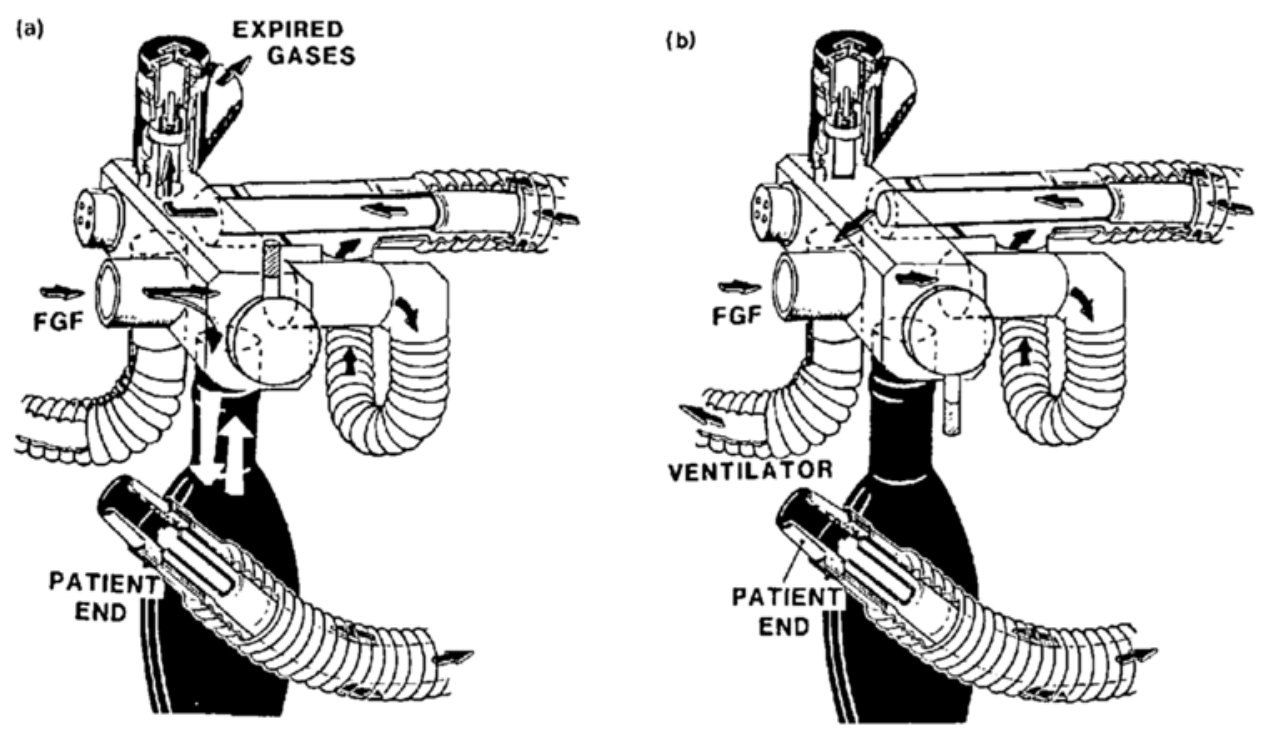

FIGURE 3 Diagram of the single lever coaxial Humphrey A.D.E. system. The same main body as in Figure 2 is used but the parallel tubing is replaced by a coaxial set. The inspiratory limb continucs as the outer tube while the expiratory limb runs concentrically inside the inspiratory limb. As such it conforms to the configuration of a Lack system. ${ }^{9.10}$ Function and fresh gas flow requirements during spontaneous respiration (a) and controlled ventilation (b) are the same as for the parallel system. A small (but not clinically important) loss of functional efficiency during spontaneous respiration occurs if the coaxial tubing connections to the main body are reversed such that the inspiratory limb nuns inside and not outside (as system $f$, Figure 7).

The purpose of this and the following paper in this issue ${ }^{7}$ is to evaluate the function of the single lever Humphrey A.D.E. system (A.D.E.) during spontaneous respiration (Part I) and controlled ventilation (Part II) in anaesthetized adult subjects. Both the coaxial and parallel versions were assessed by direct comparison with the original A.D.E., the Magill and the Bain systems. The reported observation relating to the improved efficiency of the A.D.E. system compared to the Magill system during spontaneous respiration ${ }^{2}$ is examined in detail.

\section{Methods}

Twenty patients requiring elective peripheral orthopaedic surgery in the supine position with the use of a tourniquet were studied. Ideal conditions were thus provided since each patient acted as his/her own control, operating time was al ways in excess of two hours and cuff anaesthesia promoted steady respiratory states due the diminished effect of surgical stimulation on ventilation. All patients gave their informed consent and the study was conducted with the approval of the Ethical and Standards Sub-Committee of the Board of the Faculty of Medicine of the University of Natal. All subjects studied weighed more than $50 \mathrm{~kg}$, were of ASA physical status I.

All patients received papaveretum $10-20 \mathrm{mg}$ IM approximately one hour preoperatively. Anaesthesia was induced with thiopentone $3-5 \mathrm{mg} \cdot \mathrm{kg}^{-1} \mathrm{IV}$. The trachea was intubated with a cuffed endotracheal tube after intravenous injection of succinylcholine $1 \mathrm{mg} \cdot \mathrm{kg}^{-1}$ and spraying of the larynx with lidocaine $40 \mathrm{mg}$. Respiration was spontaneous after recovery from the effects of succinylcholine. Anaesthesia was maintained with halothane 0.51.5 per cent in nitrous oxide and oxygen (2:1) without supplementary analgesics.

\section{Apparatus and sampling}

The production model of the parallel single lever Humphrey A.D.E. system (M\&IE, Ltd., Exeter, England) and prototype coaxial connector and tubing attached to the same A.D.E. main valve block were compared to standard production 
TABLE I Comparative physical properties of the A.D.E., Magill and Bain systems used in this study

\begin{tabular}{|c|c|c|c|c|}
\hline & \multicolumn{2}{|c|}{$\begin{array}{l}\text { A.D.E. } \\
\text { (single or dual lever) }\end{array}$} & \multirow[b]{2}{*}{ Magill } & \multirow[b]{2}{*}{ Bain } \\
\hline & coaxial & parallel & & \\
\hline Length (metres) & 1.58 & 1.56 & 1.0 & 1.8 \\
\hline ID parallel, single or outer tube (mm) & 28 & 22 & 22 & 22 \\
\hline ID inner tube (mm) & 15 & N/A & N/A & 7 \\
\hline Volume of inspiratory limb (ml) & 693 & 593 & 500 & 69 \\
\hline Volume of expiratory limb (ml) & 279 & 593 & $N / A$ & 615 \\
\hline Mass at patient's face (gm)* & 190 & 140 & 250 & 220 \\
\hline $\begin{array}{l}\text { Expiratory resistance at } 30 \mathrm{~L} \cdot \mathrm{sec}^{-1}(\mathrm{~Pa}) \\
\left(\mathrm{FGF} \text { set at } 5 \mathrm{~L} \cdot \mathrm{min}^{-1}\right)^{\dagger}\end{array}$ & 220 & 220 & 200 & 230 \\
\hline Dead space - water displacement $(\mathrm{ml}) \ddagger$ & 4 & 4 & 6 & 11 \\
\hline
\end{tabular}

*Each system was connected to an anaesthetic machine while the patient end was weighed

at the same height and at a distance of one metre from the machine, thus approximating normal clinical use.

†Measured with a simple water manometer.

¥The physical apparatus dead space (as measured here) may be substantially different from the functional dead space.

models of the original parallel dual lever Humphrey A.D.E. system (ABSS, Worthen, Shropshire, England), a Magill system (Penlon Ltd., Abingdon, Oxon, England), and a Bain breathing system (Ohmeda (BOC), London NW2, England). The physical properties of these systems are compared in Table I.

The apparatus and sampling arrangements are summarised in Figure 4. During anaesthesia, only the breathing system under test was altered, thus ensuring controlled conditions for within-patient comparison of the systems. Fresh gas flows were set as required on rotameters previously checked for accuracy (to within \pm 2 per cent) with a ParkinsonCowan dry gas meter. The expiratory valves on all systems were kept fully open during spontaneous respiration. After changing from one system to another, the anaesthetic system was flushed and filled with 100 per cent oxygen, using the emergency oxygen control, without alteration to the rotameter settings.

Midstream gases were analysed at the junction of the endotracheal tube and catheter mount, the latter being of sufficient volume to ensure no dilution of expired gas by fresh gas (as could occur particularly with the Bain system). Subsequent to completion of our studies, this sampling site has been shown to be reliable. ${ }^{8}$ During surgery respiratory gases were analysed continuously for carbon dioxide $\left(\mathrm{CO}_{2}\right)$ using a Hewlett Packard Capnometer with recorder, previously checked with room air for zero and a certified mixture of 5.3 per cent $\mathrm{CO}_{2}$ in oxygen and nitrogen. A mixture of 70 per cent $\mathrm{N}_{2} \mathrm{O}$ and 30 per cent $\mathrm{O}_{2}$ did not alter zero levels. In-line analysis avoided the necessity to remove gas from the system.

A minimum of 30 minutes was allowed to elapse from induction of anaesthesia to the time recording began. Initially all systems were compared in random order (unmarked sealed envelopes) and then repeated again in each subject if there was sufficient time. However, this procedure was subsequently modified since the Bain system caused such marked rebreathing, with $\mathrm{CO}_{2}$ retention, that a prolonged period of time was required to establish a new equilibrium. While the order of the other systems remained random, the Bain system was studied last. Minimum inspired and end-expired $\mathrm{CO}_{2}$ tensions were recorded once the capnograph trace had remained stable for at least five minutes. If two complete sets of recordings were made for a patient, the average of the two readings for each parameter recorded with each system is reported.

\section{Clinical trials}

Investigations in spontaneously breathing subjects were conducted with both coaxial and parallel versions of the single lever $\underline{A}$.D.E. system set in the 


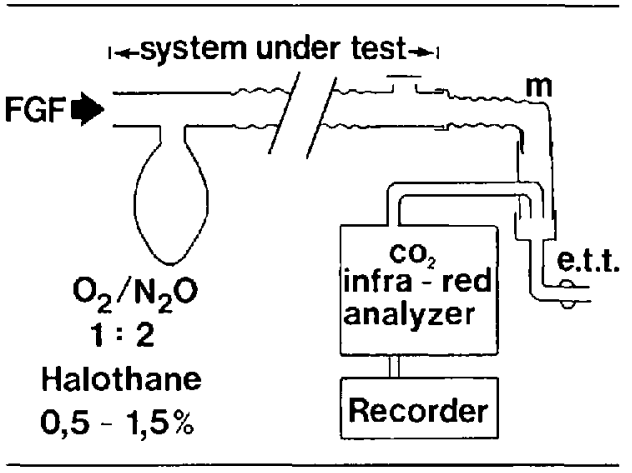

FIGURE 4 Diagram of apparatus arrangement: $m=$ catheter mount, e.t.t. = endotracheal tube. On reaching a steady state, only the breathing system under test was altered, the patient acting as his/her own control. Simultaneous rises in inspired and end-expired carbon dioxide tensions were taken as evidence of rebreathing. (Reproduced from Humphrey, ${ }^{10}$ with permission.)

"Mapleson A" mode (Figures 1, 2a, 3a), achieved by positioning the lever upright. Similarly the dual lever A.D.E. system was set in the Mapleson A mode (both levers upright). Within-patient comparisons in ten subjects were made between the three A.D.E., Magill and Bain systems, the FGF being set at $70 \mathrm{ml} \cdot \mathrm{kg}^{-1} \cdot \mathrm{min}^{-1}$. A further comparison was made between the single lever parallel A.D.E., the Magill and Bain systems with the FGF reduced to $45 \mathrm{ml} \cdot \mathrm{kg}^{-1} \cdot \mathrm{min}^{-1}$.

The minimum FGFs required for each system to just induce rebreathing were also studied using within-patient comparisons. The FGF at which each of the five systems began to cause rebreathing of alveolar gases was determined by providing a fresh gas flow in excess of the predicted requirements, and then reducing the flow by increments of $100 \mathrm{ml} \cdot \mathrm{min}^{-1}$ to the point at which minimum inspired carbon dioxide tension $\left(\mathrm{PlCO}_{2}\right)$ rose from zero to $2 \mathrm{mmHg}$ ( 0.3 per cent). The FGF requirements of both versions of the single lever A.D.E. system set in the " $A$ " mode were compared in ten patients to those for the dual lever A.D.E. (also in the A mode), the Magill and Bain systems.

The change from spontaneous respiration to controlled ventilation or vice versa with the A.D.E system is examined in Part II. $^{7}$

Data were subjected to statistical analysis using a paired Student's $t$ test. $P$ values $\leqslant 0.05$ were regarded as significant

\section{Results}

The results from the first ten patients studied are given in Table II and Figure 5.

TABLE II Inspired and end-expired carbon dioxide tensions recorded from 10 anaesthetized patients breathing spontaneously under identical conditions with a fixed fresh gas flow of $70 \mathrm{ml} \cdot \mathrm{kg}^{-1} \cdot \mathrm{min}^{-1}$

\begin{tabular}{|c|c|c|c|c|c|c|c|c|c|c|c|}
\hline \multirow[b]{2}{*}{ Patient } & \multirow[b]{2}{*}{$\begin{array}{l}\text { Age } \\
y r\end{array}$} & \multirow[b]{2}{*}{$\begin{array}{l}\text { Weight } \\
\text { kg }\end{array}$} & \multirow[b]{2}{*}{$\begin{array}{l}F G F \\
L \cdot m i n^{-1}\end{array}$} & \multicolumn{2}{|c|}{$\begin{array}{l}\text { A.D.E. } \\
\text { single lever* }\end{array}$} & \multicolumn{2}{|c|}{$\begin{array}{l}\text { A.D.E. } \\
\text { dual level }\end{array}$} & \multicolumn{2}{|l|}{ Magill } & \multicolumn{2}{|l|}{ Bain } \\
\hline & & & & $\begin{array}{l}\mathrm{PICO}_{2} \\
\mathrm{mmHg}\end{array}$ & $\begin{array}{l}\text { PECO } \\
\mathrm{mtmHg}\end{array}$ & $\begin{array}{l}\mathrm{PlCO}_{2} \\
\mathrm{~mm} / \mathrm{g}\end{array}$ & $\begin{array}{l}\mathrm{PECO} \\
\mathrm{mmHg}\end{array}$ & $\begin{array}{l}\mathrm{PICO}_{2} \\
\mathrm{mmHg}\end{array}$ & $\begin{array}{l}\mathrm{PECO}_{2} \\
\mathrm{mmHg}\end{array}$ & $\begin{array}{l}\mathrm{PICO}_{2} \\
\mathrm{mmHg}\end{array}$ & $\begin{array}{l}\mathrm{PECO} \\
\mathrm{mmHg}\end{array}$ \\
\hline 1 & 40 & 55 & 3.8 & 1 & 41 & 1 & 42 & 2 & 46 & 32 & 59 \\
\hline 2 & 39 & 80 & 5.6 & 0 & 46 & 1 & 47 & 4 & 51 & 35 & 54 \\
\hline 3 & 18 & 57 & 4.0 & 0 & 55 & 0 & 55 & 2 & 56 & 31 & 61 \\
\hline 4 & 24 & 60 & 4.2 & 1 & 47 & 0 & 46 & 2 & 50 & 26 & 56 \\
\hline 5 & 50 & 65 & 4.6 & 0 & 51 & 0 & 51 & 2 & 54 & 26 & 58 \\
\hline 6 & 26 & 63 & 4.5 & 0 & 46 & 0 & 46 & 2 & 51 & 31 & 57 \\
\hline 7 & 15 & 36 & 2.5 & 1 & 49 & 1 & 49 & 3 & 53 & 32 & 58 \\
\hline 8 & 26 & 61 & 4.3 & 2 & 50 & 2 & 51 & 4 & 54 & 20 & 56 \\
\hline 9 & 33 & 51 & 3.6 & 0 & 37 & 0 & 37 & 1 & 41 & 17 & 46 \\
\hline 10 & 18 & 59 & 4.2 & 2 & 53 & 2 & 52 & 5 & 56 & 37 & 62 \\
\hline Mean & 28.9 & 58.7 & 4.13 & 0.7 & 47.5 & 0.7 & 47.6 & 2.7 & 51.2 & 28.7 & 56.7 \\
\hline SD & \pm 11.3 & \pm 11.1 & \pm 0.79 & & \pm 5.42 & & \pm 5.25 & & \pm 4.69 & \pm 6.40 & \pm 4.45 \\
\hline
\end{tabular}

* Since no differences were observed between the coaxiai and parallel single lever A.D.E. systems, results relate to both versions. While there were no statistically significant differences betwecn any A.D.E. systems for either inspired or end-expired $\mathrm{CO}_{2}$ tensions, differences in both these parameters between all three A.D.E. systems and the Magill or Bain systems were highly significant $(p<0.001)$. 


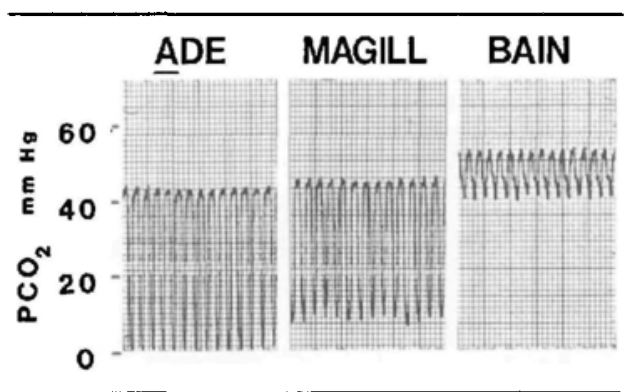

FIGURE 5 Comparative function of the single lever A.D.E., Magill and Bain systems during spontaneous respiration is shown in a typical capnograph trace. In a subject weighing $67 \mathrm{~kg}$ the fresh gas flow was reduced to $45 \mathrm{ml} \cdot \mathrm{kg}^{-1} \cdot \mathrm{min}^{-1}$ ( $\left.3 \mathrm{~L} \cdot \mathrm{min}^{-1}\right)$, At this flow the A.D.E. caused no apparent rebreathing, minimum inspircd $\mathrm{CO}_{2}$ tensions being zero. Rebreathing, as seen by simultaneous rises in both inspired and end-expired dioxide tensions, is evident when the Magill circuit was subsequently used at the same FGF. The Bair circuit caused an even more marked increase in both parameters, the rise in end-expired $\mathrm{CO}_{2}$ tensions being $10 \mathrm{mmHg}$.

No differences were recorded in inspired and end-expired $\mathrm{CO}_{2}$ tensions with the parallel (noncoaxial) and coaxial versions of the single lever A.D.E. system. Hence all the results recorded for the single lever A.D.E. system therefore apply to both versions, unless specified otherwise. While there were no statistically significant differences between the single and dual lever A.D.E. systems for either inspired or end-expired $\mathrm{CO}_{2}$ tensions, differences in both parameters between all three A.D.E. systems and the Magill or Bain systems were significant $(p<0.001)$.

The comparative fresh gas flows recorded from a further ten subjects for each system at the point where rebreathing was just induced are summarised in Table III. Both coaxial and parallel single lever A.D.E. systems requried a mean flow of 51.4 $\mathrm{ml} \cdot \mathrm{kg}^{-1} \cdot \mathrm{min}^{-1}$, almost identical to that required by the dual lever parallel systems $\left(51.7 \mathrm{ml} \cdot \mathrm{kg}^{-1} \cdot \mathrm{min}^{-1}\right)$. By comparison the Magill system required 71.2 $\mathrm{ml} \cdot \mathrm{kg}^{-1} \cdot \mathrm{min}^{-1}$ while the Bain system necessitated using much higher flows of $149.5 \mathrm{ml} \cdot \mathrm{kg}^{-1} \cdot \mathrm{min}^{-1}$. While there were no statistically significant differences between any of the A.D.E. systems, differences between all A.D.E. systems and the Magill or the Bain systems were highly significant $(p<$ 0.001 ).

\section{Discussion}

The anaesthetic breathing system requirements for inhalational anaesthesia without carbon dioxide

TABLE III Comparative fresh gas flows required by the various breathing systems used in this study to just induce rebreathing in anaesthetized adults

\begin{tabular}{|c|c|c|c|c|c|c|}
\hline \multirow[b]{2}{*}{ Patient } & \multirow[b]{2}{*}{$\begin{array}{l}\text { Age } \\
y r\end{array}$} & \multirow[b]{2}{*}{$\begin{array}{l}\text { Weight } \\
\mathrm{kg}\end{array}$} & \multicolumn{4}{|c|}{ Fresh gas flow $-m i \cdot \mathrm{kg}^{-1} \cdot \mathrm{min}^{-1}$} \\
\hline & & & $\begin{array}{l}\text { A.D.E. } \\
\text { single } \\
\text { lever* }\end{array}$ & $\begin{array}{l}\text { A.D.E. } \\
\text { dual } \\
\text { lever }\end{array}$ & Magill & Bain \\
\hline 1 & 18 & 68 & 56 & 56 & 78 & 168 \\
\hline 2 & 27 & 72 & 53 & 52 & 71 & 151 \\
\hline 3 & 43 & 75 & 47 & 47 & 67 & 139 \\
\hline 4 & 25 & 65 & 54 & 55 & 69 & 150 \\
\hline 5 & 47 & 59 & 45 & 46 & 65 & 127 \\
\hline 6 & 19 & 68 & 56 & 57 & 74 & 155 \\
\hline 7 & 23 & 57 & 50 & 50 & 69 & 139 \\
\hline 8 & 17 & 74 & 59 & 60 & 84 & 176 \\
\hline 9 & 51 & 65 & 43 & 43 & 65 & 130 \\
\hline 10 & 21 & 71 & 51 & 51 & 70 & 160 \\
\hline Mean & 29.1 & 67.4 & 51.4 & 51.7 & 71.2 & 149.5 \\
\hline $\mathrm{SD}$ & \pm 12.8 & \pm 6.0 & \pm 5.2 & \pm 5.4 & \pm 6.0 & \pm 16.0 \\
\hline \multirow{2}{*}{\multicolumn{3}{|c|}{$\begin{array}{l}\text { Mean FGF }-L \cdot \min ^{-1} \\
\text { SD }\end{array}$}} & 3.46 & 3.48 & 4.8 & 10.1 \\
\hline & & & \pm 0.35 & \pm 0.36 & \pm 0.4 & \pm 1.1 \\
\hline
\end{tabular}

*Since no differences were observed between the coaxial and parallel single lever A.D.E. systems, results relate to both versions.

Differences between the FGFs for the A.D.E. systems were not statistically significant, though differences between all A.D.E. systems and the Magill or Bain systems were highly significant $(p<0.001)$. 
absorption can be met in everyday practice by using Mapleson A, D and E systems. Well-known systems include the Magill (Mapleson A), Lack ${ }^{9,10}$ (modified coaxial Mapleson A), Bain ${ }^{11}$ (modified coaxial Mapleson D/E) and T-piece (Mapleson E). These may be used either in adults or children or for spontaneous respiration or controlled ventilation. While only the Bain circuit has been used in all these circumstances it does not, however, serve a "universal" function efficiently. Indeed, the controversy whether the convenience of the Bain circuit outweighs the necessity to use high fresh gas flows for spontaneous respiration continues unabated. ${ }^{12-20}$ The Bain circuit requires two to three times the FGF required by Mapleson A systems, ${ }^{10,20-24}$ and as a result inspired humidity with the Bain system is reduced ${ }^{25}$ and potential theatre pollution increased.

A system combining Mapleson A, D and E principles would therefore appear to offer advantages. Specialist anaesthetists and especially those in training would benefit by the use of a single system for all patients, the operating room staff by a reduction in potential theatre pollution, administrators by reduced costs, and patients from the increase in warmth and humidity of anaesthetic gases associated with low fresh gas flows. ${ }^{25}$ These goals were the aims behind the design and function of the original dual lever A.D.E. systems, ${ }^{4}$ further simplified in the single lever version. ${ }^{6}$

Examination of the function of the single lever A.D.E. system shows that, for spontaneous respiration in the " $A$ " mode, both parallel (non-coaxial) and coaxial versions of the single lever A.D.E. system behaved predictably, consistently and similarly to the original dual lever version of the A.D.E. system. All three A.D.E. systems required a mean FGF of $51-52 \mathrm{ml} \cdot \mathrm{kg}^{-1} \cdot \mathrm{min}^{-1}$ to prevent rebreathing of alveolar gases (Table III). Under identical conditions, this FGF was significantly less than that for the Magill circuit (mean $71 \mathrm{ml} \cdot \mathrm{kg}^{-1} \cdot \mathrm{min}^{-1}$ ) and for the Bain circuit (mean $150 \mathrm{ml} \cdot \mathrm{kg}^{-1} \cdot \mathrm{min}^{-1}$ ). Compared to the A.D.E., rebreathing with the Magill circuit and particularly the Bain circuit was clearly evident at a FGF of $70 \mathrm{ml} \cdot \mathrm{kg}^{-1} \cdot \mathrm{min}^{-1}$ (Table II) and at lower FGFs required by the A.D.E. to prevent rebreathing (Figure 5). Our results confirm both Dixon et al.' ${ }^{2}$ observations that the dual lever A.D.E. required a significantly lower mean FGF than the Magill circuit, and Shulman and Brodsky's ${ }^{3}$ additional report on the FGF requirements of the dual lever system during spontaneous respiration $\left(56 \mathrm{ml} \cdot \mathrm{kg}^{-1} \cdot \mathrm{min}^{-1}\right)$. That the single lever version should function identically comes as no surprise. The potential problem with the dual lever system $^{26,27}$ now appears to have been solved by a single lever system. In addition it avoids the pitfalls of other alternative single lever multipurpose systems, ${ }^{28-30}$ all of which can be potential. ly lethal without the anaesthetists being aware that anything is amiss. ${ }^{31}$ This is discussed further in Part II.

While the three-fold increase in efficiency of the A.D.E. system over the Bain circuit was predictable, its apparent improved efficiency over the Magill circuit for spontaneous respiration is controversial, since the latter observation would appear to be impossible. ${ }^{32-35}$ For many years the Magill circuit has been accepted as utilizing fresh gas with maximal efficiency, requiring a FGF approximating alveolar ventilation. ${ }^{32-34}$ Hence the Magill circuit has been thought to be nearly 100 per cent efficient. This view was supported mathematically by Conway. ${ }^{35}$ However, these conclusions ${ }^{32-35}$ appear inconsistent with the results reported here and confirmed by others in anaesthetized patients, ${ }^{2}$ for the A.D.E. system required between 19-28 per cent less FGF than the Magill circuit before rebreathing became evident.

Conway suggested that the methodology used in this and other of our studies ${ }^{10}$ is questionable ${ }^{36}$ and that any observed variations between systems examined are merely differences in experimental technique. ${ }^{37}$ We have examined our own methodology which we feel has eliminated any patient or anaesthetic machine variation. Since in each subject only the breathing systems under examination were changed, without alteration to any other parameter, our comparisons would appear valid and, more importantly, directly comparable. Few other studies have employed this methodology, for most earlier work on the Magill system has simply involved measurements without comparison, the results being interpreted in relation to the then current knowledge of respiratory physiology. We have always used anaesthetized subjects undergoing surgery, since the problems of the effects of consciousness on respiratory drive and effort are avoided; the latter can have a significant effect on results, as was the experience of Dixon et al. ${ }^{2}$ It is also well known that significant physiological changes occur under anaesthesia, making direct 
interpretation of data obtained in awake subjects suspect. The conditions that we created for our studies are those encountered in clinical practice, adding to the practical validity of our results.

The detection of increasing minute ventilation might have provided useful additional evidence of rebreathing in this study, but we found that, in practice, all spirometers avalable to us were inconsistent and sometimes widely inaccurate when tested against a Starling pump. Consequently, we did not attempt this measurement. However, since measurement of total minute ventilation is not a direct assessment of rebreathing but rather an objective response by the patient (often depressed by premedication and anaesthetic drugs), we felt it reasonable to regard the simultaneous rise in both minimum inspired and end-expired $\mathrm{CO}_{2}$ tensions as being evidence that rebreathing was occurring. ${ }^{38}$ Thus, comparison of these simultaneous rises in $\mathrm{PICO}_{2}$ and $\mathrm{PECO}_{2}$, which had been recorded under identical conditions from the same anaesthetized patient with the same FGF, were considered as indicative of the degree of rebreathing caused by a particular system. Further comment has already been made on the sensitivity of our methods in detecting the onset of rebreathing. ${ }^{19}$

While we uphold the validity of our own and independent studies on the A.D.E. system, further theoretical and clinical evidence suggests that the Magill circuit may not be as efficient as has been widely believed. If rebreathing of alveolar gases is to be prevented, the theoretical minimum FGF into a breathing system need only be equal to alveolar ventilation. This is possible only if that the whole volume occupying "dead space" in the patient's lungs is preserved in the inspiratory limb of the system and utilized during the next breath. Such a theory was postulated for the Magill circuit. ${ }^{32}$ Alveolar ventilation is difficult to measure clinically but it can be theoretically calculated for any $\mathrm{PECO}_{2}$ if carbon dioxide output $(\mathrm{\kappa VCO})_{2}$ is known. ${ }^{39}$ The latter has been shown by Bain and Spoerel ${ }^{40}$ to be about $2.5 \mathrm{ml} \cdot \mathrm{kg}^{-1} \cdot \mathrm{min}^{-1}$ in anaesthetized adults. Therefore to maintain normocarbia, alveolar ventilation would need to be about 45 $\mathrm{ml} \cdot \mathrm{kg}^{-1} \cdot \mathrm{min}^{-1}$ if these figures are substituted into the alveolar air equation. ${ }^{39}$ However, in this study, mean $\mathrm{PECO}_{2}$ with the A.D.E. system was 47.5 $\mathrm{mmHg}$, probably as a result of drug-induced respiratory depression. During spontaneous respiration, arterial carbon dioxide tensions generally increase

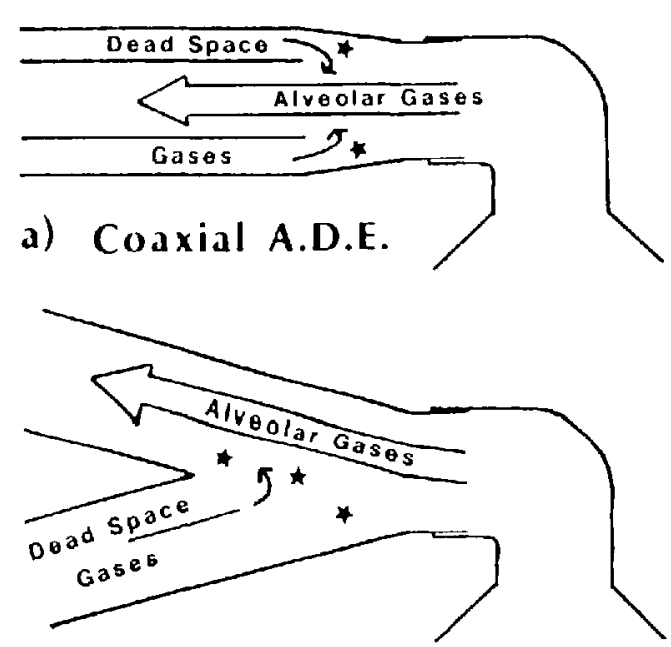

b) Parallel (Non-coaxial) A.D.E.

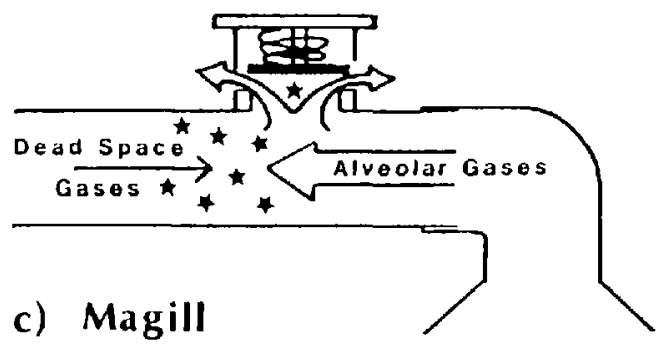

FIGURE 6 With a FGF close to alveolar ventilation, the theoretical flow dynamics of expired gases are shown for (a) the A.D.E. coaxial, (b) A.D.E. parallel, and (c) Magill systems. During the initial half of expiration dead space gases return to the inspiratory limb. If these gases are to be rebreathed without increasing the inspiratory carbon dioxide load, alveolar gases must be subsequently vented with minimal mixing. Conditions for laminar flow are therefore required. The geometrical arangements of the components of both A.D.E. systems promote this. With the Magill circuit, a marked degree of turbulence and mixing (as shown by the asterixes) is inevitable for alveolar gases flow directly contrary to that of dead space gases and must also be redirected up through the exhaust valve. The relative FGF must be increased to eliminate $\mathrm{CO}_{2}$ contaminated dead space gas.

to between 5.3 and $8.7 \mathrm{kPa}(40-65 \mathrm{mmHg}) .{ }^{41}$ At a $\mathrm{CO}_{2}$ tension of $47.5 \mathrm{mmHg}$ (within this normal range), the mean alveolar ventilation of our subjects can be recalculated at about $37 \mathrm{ml} \cdot \mathrm{kg}^{-1} \cdot \mathrm{min}^{-1}$ (if ${ }_{10 V C O}$ was assumed to be $2.5 \mathrm{ml} \cdot \mathrm{kg}^{-1} \cdot \mathrm{min}^{-1}$ ). The FGF of $51 \mathrm{ml} \cdot \mathrm{kg}^{-1} \cdot \mathrm{min}^{-1}$ recorded in our 
studies of the A.D.E. system thus exceeds the calculated alveolar ventilation by $14 \mathrm{ml} \cdot \mathrm{kg}^{-1} \cdot \mathrm{min}^{-1}$. Hence, not only has this FGF been shown to be adequate in clinical practice but it is also higher than the theoretical minimum calculated for our study.

A second conclusion from these calculations indicate that a little dead space gas must have been lost with each breath. This would be expected as no system is ever likely to be 100 per cent efficient, even under ideal conditions in which mixing of dead space and alveolar gases is reduced to a minimum. The loss of dead space gas appears to have been more significant with the Magill circuit, and indeed little can have been conserved as the FGF needed to prevent rebreathing $\left(71 \mathrm{ml} \cdot \mathrm{kg}^{-1} \cdot \mathrm{min}^{-1}\right)$ was double the calculated alveolar ventilation (37 $\left.\mathrm{ml} \cdot \mathrm{kg}^{-1} \cdot \mathrm{min}^{-1}\right)$. This suggestion is consistent with Humphrey's theoretical flow analysis for the Magill circuit during the second half of expiration, once the exhaust valve has opened, ${ }^{10}$ for the placing of an exhaust valve at the critical physical point where alveolar and dead space gases are separated is particularly likely to disturb gas flow (Figure 6c). Considerable turbulance results with consequent gas mixing and contamination of dead space gas. Humphrey also proposed that the efficiency of Mapleson A systems appeared to be related to the geometrical design that best promoted laminar flow of expired gases into the expiratory limb. ${ }^{10} \mathrm{He}$ suggested that by effectively preventing contamination of dead space gases by alveolar gases, rebreathing of carbon dioxide can be reduced allowing a similar reduction in the FGF requirement. Support for these theories would appear to be forthcoming from this study, for we suggest that the geometrical arrangements of the components of both coaxial and parallel versions of the A.D.E. systems promote laminar flow since alveolar gases flow into the expiratory limb with little or no change in direction (Figure 6a and $\mathrm{b}$ ).

Another useful guide to assess the efficiency of any system is to calculate the fractional utilization of fresh gas ( $f$ ) using the following equation. ${ }^{35}$

$$
f=\frac{\dot{V} \mathrm{VO}_{2}\left(\mathrm{ml} \cdot \mathrm{kg}^{-1} \cdot \mathrm{min}^{-1}\right)}{\mathrm{FGF}\left(\mathrm{ml} \cdot \mathrm{kg}^{-1} \cdot \mathrm{min}^{-1}\right) \times \mathrm{FECO}_{2} \%}
$$

Again assuming the mean $\dot{\mathrm{V}} \mathrm{CO}_{2}$ to be $2.5 \mathrm{ml}$. $\mathrm{kg}^{-1} \cdot \mathrm{min}^{-1}$, the $\mathrm{f}$ value for spontaneous respiration for the A.D.E. in this study is 0.73 (i.e., the A.D.E. utilizes 73 per cent of the fresh gas while 27 per cent mixes with alveolar gas and must be expelled from the system if rebreathing is to be prevented). This value is 0.51 for the Magill circuit and 0.24 for the Bain circuit. These figures for the Magill and Bain circuits are very similar to those obtained by Rose et al. ${ }^{14}$ using a lung model (programmed for a $\dot{\mathrm{V}} \mathrm{CO}_{2}$ value of $\left.2.57 \mathrm{ml} \cdot \mathrm{kg}^{-1} \cdot \mathrm{min}^{-1}\right)$. The $\mathrm{f}$ value was 0.57 for the Magill circuit and 0.23 for the Bain circuit. Both calculations for the Magill circuit (based on clinical and laboratory observations) contrast with Conway's mathematical calculation in which he predicted $f$ would be equal to unity, i.e., the Magill circuit utilized 100 per cent of the fresh gas. ${ }^{35}$ If this prediction was correct and normocarbia was maintained, the Magill circuit should prevent rebreathing with a FGF of $45 \mathrm{ml} \cdot \mathrm{kg}^{-1} \cdot \mathrm{min}^{-1}$ (again assuming $\stackrel{\vee}{\mathrm{V}} \mathrm{CO}_{2}$ to be $2.5 \mathrm{ml} \cdot \mathrm{kg}^{-1} \cdot \mathrm{min}^{-1}$ ). No clinical study has shown this.

Analysis of the work by Kain and $\mathrm{Nunn}^{32}$ reveals the $f$ value to be 0.63 for the Magill circuit in their anaesthetized patients ( $10 \mathrm{VCO}_{2}$ again assumed to be $2.5 \mathrm{ml} \cdot \mathrm{kg}^{-1} \cdot \mathrm{min}^{-1}$ ). Calculation of the $\mathrm{f}$ value from the study on the Magill system by Norman et al. ${ }^{33}$ would have been interesting, but the actual $\mathrm{FECO}$ values were not stated, nor was the study conducted on anaesthetized subjects. Conway et al.$^{34}$ give no data in their study using the Magill circuit with conscious volunteers, neither was any indication given as to how "predicted alveolar ventilation" was calculated. While any further interpretation of their results is consequently impossible, they clearly state that: "In every subject and in every study, evidence of alveolar gas was seen when the fresh gas flow approached the alveolar ventilation level." They also comment that at this FGF most subjects progressively went through a period of mild, moderate and finally marked rebreathing when the inspired carbon dioxide concentration increased to three per cent or more, with a marked increase in ventilation. From this study the Magill system was concluded a require a FGF above alveolar ventilation, though no attempt was made to quantify this. From our experience in anaesthetised patients, we surmise that the FGF would have had to be substantially higher to prevent the marked rebreathing observed.

There is thus an apparent general agreement between the findings of this current study and previous work; no discrepancy exists. However, the interpretation of earlier data on the Magill system that the FGF required approximated alveolar venti. 
lation was probably related to respiratory physiology of the awake rather than anaesthetized subject. Kain et $a l^{42}$ continued their studies on anaesthetized subjects and found that the mean functional dead space in intubated patients was 46 per cent of the tidal volume. Mean alveolar ventilation would therefore be only 54 per cent of the total minute ventilation. This value subsequently contrasts with the 71 per cent ratio normally associated with awake subjects and assumed by Kain and Nunn in their earlier paper on the Magill circuit. ${ }^{32}$ This difference would account for their original belief that the Magill circuit appeared to function with maximum efficiency.

Finally, Spoerel et al. ${ }^{43}$ made a comparison between, amongst others, the Magill circuit and the circle system with absorption, using a FGF of $70 \mathrm{ml} \cdot \mathrm{kg}^{-1} \cdot \mathrm{min}^{-1}$ in patients under halothane anaesthesia, with no premedication. Compared to the circle absorber, the Magill circuit caused a mean rise in $\mathrm{PaCO}_{2}$ of $4 \mathrm{mmHg}(0.53 \mathrm{kPa})$ and a 17 per cent increase in mean respiratory minute volume. At a FGF which should have been adequate, the Magill circuit clearly caused some rebreathing, compared to the circle absorber, which must be assumed was efficiently absorbing $\mathrm{CO}_{2}$. It is interesting that the circle absorber system (in Spoerel's study) and the A.D.E. (in this study) both caused similar falls in $\mathrm{PaCO}_{2}$ or $\mathrm{PECO}_{2}$ compared to the Magill circuit when the same FGF (70 $\mathrm{ml} \cdot \mathrm{kg}^{-1} \cdot \mathrm{min}^{-1}$ ) was used.

Hence both clinical, laboratory and further theoretical evaluation of the results of previous studies support the observations of this study that the Magill circuit is between 51-63 per cent efficient, and that its relative inefficiency leaves room for improvement. Our observations on the A.D.E. system are therefore plausible.

Having reached this conclusion, we conducted further trials to examine what design or component features of the A.D.E. system might have caused this functional advantage over the Magill circuit. Indeed, could the A.D.E. system be further improved in design since it was only 73 per cent efficient? While the detail of these trials is outside the scope of this paper, relevant findings are summarised here. In our quest to establish whether the components themselves altered the performance of Mapleson A systems, we used a variety of different expiratory valves and substituted smooth instead of corrugated tubing. Using the same

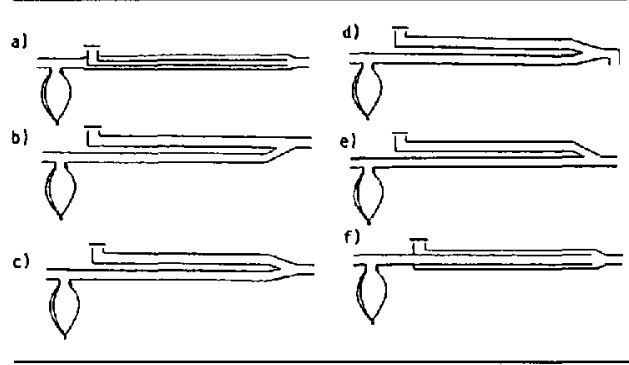

FGURE 7 Diagrans of six experimental Mapleson A variant breathing systems. Using the anaesthetized subject as his own control, the efficiency of each was compared, the volumes of the inspiratory limbs and the resistances of the exhaust valves being similar. Systems "a-d" functioned similarly, while " $e$ " and "f" caused more rebreathing at the same FGF. Efficiency appeared to be related to the flow of expired gases directly into the expiratory limb with a minimal change in direction.

methodology as described above, these alterations did not affect our observations. The volume of the expiratory limb of the A.D.E. system appeared not to be critical. However, the minimum volume of the inspiratory limb needed to exceed half the tidal volume to ensure that alveolar gas did not reach the reservoir bag and cause considerable rebreathing. We found that a volume of $250 \mathrm{ml}$ was sufficient in clinical practice since tidal volumes do not tend to be larger than $500 \mathrm{ml}$ in adequately anaesthetized subjects. In Kain and Nunn's study on the Magill circuit $^{32}$ the average tidal volume was $260 \mathrm{ml}$. Even when they deliberately induced rebreathing by reducing the FGF from a mean of 6.4 to $2.5 \mathrm{~L} \cdot \mathrm{min}^{-1}$, tidal volumes increased to a mean of $425 \mathrm{ml}$.

As shown in Figure 7, six modifications of Mapleson A systems were also evaluated to see if component sequence or design influenced function. The coaxial (system 7a) and parallel (system 7c) A.D.E. systems could not, in fact, be improved. Functionally, systems $7 b$ and $7 d$ were no less efficient. Systems $7 e$ and $7 f$ were the least efficient. It was concluded that the most efficient Mapleson A systems consisted of two limbs. The inspiratory limb (placed outside the expiratory tube in the coaxial version as in the Lack) had an inspiratory reservoir bag near the anaesthetic machine, with a " $Y$ " or coaxial connector at the patient's face. The latter connector was attached to the expiratory limb into which alveolar gases could pass unhindered 
from the patient with a minimum change in direction. These gases were vented from the expiratory tube through an exhaust valve placed well away form the junction of the two limbs and conveniently at the anaesthetic machine. The efficient systems thus all met the conditions described by Humphrey under which dead space gas would be best preserved. ${ }^{10}$

In conclusion, the single lever Humphrey A.D.E. system in the " $A$ " mode for spontaneous respiration has been shown to be simple, safe and efficient. Since rebreathing became evident only with a mean FGF of $51 \mathrm{ml} \cdot \mathrm{kg}^{-1} \cdot \mathrm{min}^{-1}$, an average flow for the A.D.E. systems would be about $3.6 \mathrm{~L} \cdot \mathrm{min}^{-1}$ for a $70 \mathrm{~kg}$ patient, a flow less than many anaesthetists use, even with carbon dioxide absorption. ${ }^{44,45}$ Such low flows can only be achieved by the preservation of dead space gases; as a result inspired gases are likely to have a high natural humidity. ${ }^{25}$ Scavenging is facilitated at the anaesthetic machine, making it possible to reduce the hazards of theatre pollution. By repositioning the lever, the A.D.E. system converts into a Mapleson E system, offering all the advantages of the Bain circuit for controlled ventilation which are discussed in Part II. ${ }^{7}$ However, the disadvantages of the Bain circuit during spontaneous respiration are avoided.

\section{Acknowledgements}

The authors would like to thank Dr. E. Mankowitz, Principal Anaesthetist, Professor Sarkin (orthopaedic surgery) and the Medical Superintendent, patients and staff of King Edward VIII Hospital, Durban, for their cooperation. Thanks are due to the Departmental Secretaries for their assistance in the preparation of this paper. Many components were donated by M\&IE Ltd., Exeter, England and Anaesthetic Breathing System Supplies, Worthen, Shrewsbury, Shropshire, England. This work was supported by research grants from the University of Natal and the Medical Research Council of South Africa.

Commercial availability: enquiries should be sent direct to the manufacturers (or their agents) and not to the authors: M\&IE Ltd., Falcon Road, Sowton Industrial Estate, Exeter, EX2 7NA, England, Dentsply Canada, Lode Star Road, Downsview, Ontario or Ohmeda Canada, 172 Belfield Road, Toronto, Ontario. The system is protected by worldwide patients.

\section{References}

1 Nunn $J F$. Applied Respiratory Physiology. Ed

2, Butterworths; London, 1977, p 233.

2 Dixon J, Chakrabarti MK, Morgan $M$. An assessment of the Humphrey A.D.E. anaesthetic system in the Mapleson A mode during spontaneous ventilation. Anaesthesia 1984; 39: 593-6.

3 Shulman JS, Brodsky JB. The A.D.E. system - a new anesthetic breathing system. Anesth Analg 1984; 63: 273

4 Humphrey $D$. A new anaesthetic breathing system combining Mapleson A, D and E principles: a simple apparatus for low how universal use without carbon dioxide absorption. Anaesthesia 1983; 38: 361-72.

5 Dennison PH. Co-axial tubing for conventional anaesthetic systems. Anaesthesia 1984; 39: 841.

6 Humphrey $D$. The A.D.E. anaesthetic breathing system. Anaesthesia 1984; 39: 715-7.

7 Humphrey D, Brock-Utne JG, Downing JW. Single lever Humphrey A.D.E. low flow universal breathing system. Part II: Comparison with the Bain system in anaesthetized adults during controlled ventilation. Can Anaesth Soc J. 1986; 33: 710-8.

8 Gravenstein N, Lampotang S, Beneken JEW. Factors influencing capnography in the Bain system. J Clin Monitoring 1985; 1: 6-10.

9 Lack JA. Theatre pollution control. Anaesthesia 1976; 31: 259-62.

10 Humphrey $D$. The Lack, Magill and Bain anaesthetic breathing systems: a direct comparison in spontaneously breathing anaesthetized adults. J Roy Soc Med 1982; 75: 513-24

11 Bain JA, Spoerel WE. A streamlined anaesthetic system. Can Anaesth Soc J 1972; 19: 426-35.

12 Goodwin K. Bain circuit. Can Anaesth Soc J 1976; 23: 675 .

13 Mansell WH. Spontaneous breathing with the Bain circuit at low flow rates: a case report. Can Anaesth Soc J 1976; 23: 432-4.

14 Rose $D K$, Byrick RJ, Froese AB. Carbon dioxide elimination during spontaneous ventilation with a modified Mapleson D system: studies in a lung model. Can Anaesth Soc J 1978; 25: 353-65.

15 Nott MR, Norman J. The Bain and Lack breathing systems. Anaesthesia 1981; 36: 635 .

16 Conway $C M$, Barnes $P K$. The Bain breathing system. Anaesthesia 1982; 37: 100-1.

17 Nott MR, Norman J. Rebreathing and the Bain circuit. Anesthesiology 1983; 58: 392-3. 
18 Dean $S E$, Keenan $R L$. Rebreathing and the Bain circuit. Anesthesiology 1983; 58: 393-4.

19 Humphrey $D$. Rebreathing and the Bain circuit. Anesthesiology 1984; 60: 80-1.

20 Alexander JP. Clinical comparisons of the Bain and Magill anaesthetic systems during spontaneous respiration. Br J Anaesth 1982; 54: 1031-6.

21 Conway $C M$, Seeley $H F$, Barnes $P K$. Spontaneous ventilation with the Bain anaesthetic system. $\mathrm{Br} J$ Anaesth 1977 ; 49: 1245-9.

22 Ungerer $M J$. A comparison between the Bain and Magill anaesthetic systems during spontaneous breathing. Can Anaesth Soc J 1978; 25: 122-4.

23 Byrick RJ. Respiratory compensation during spontaneous ventilation with the Bain circuit. Can Anaesth Soc J 1980; 27: 96-105.

24 Nott MR, Walters FJM, Norman J. The Lack and Bain systems in spontaneous respiration. Anaesth Intensive Care 1982; 10: 333-9.

25 Flynn PJ, Morris LE. Humidity in anaesthetic systems. Br J Anaesth 1981; 53: 1096.

26 Taylor MB. A suggestion. Anaesthesia 1983; 38: 906.

27 Newton $N$, Cundy $J M$. The ultimate goal? Anaesthesia $1983 ; 38$ : 906-7.

28 Burchett KR, Bennett JA. A new co-axial breathing system; a combination of the benefits of Mapleson

A, D and E systems. Anaesthesia 1985; 40: 181-7.

29 Ramaya GP. Multi-mode switchable breathing systems. Anaesthesia 1985; 40: 706-7.

30 Manicom AW, Schoonbee CG. The Johannesburg A-D circuit switch; a valve device for converting a co-axial Mapleson D into a co-axial Mapleson A system. Br J Anaesth 1979; 51: 1185-7.

31 Humphrey $D$. A new coaxial breathing system. Anaesthesia 1985; 40: 1136-7.

32 Kain ML, Nunn JF. Fresh gas economics of the Magill system. Anesthesiology 1968; 29: 964-74.

33 Norman J, Adams AP, Sykes $M K$. Rebreathing with the Magill attachment. Anesthesia 1968; 23: 75-81.

34 Conway CM, Davis FM, Knight HJ, Leigh JM, Preston TD, Tennant $R$. An experimental study of gaseous homeostasis and the Magill circuit using low fresh gas flows. Br J Anaesth 1976; 48; 447-55.

35 Conway $C M$. Alveolar gas relationships during the use of semi-closed rebreathing anaesthetic systems. Br J Anaesth 1976; 48: 865-9.

36 Barnes $P K$, Conway $C M$. The Lack system - a further reply. Anaesthesia 1983; 38: 603.
37 Conway $C M$. Anaesthetic breathing systems. Br J Anaesth 1985; 57: 649-57.

38 Humphrey D. Rebreathing and the Bain circuit. Can Anaesth Soc J 1984; 31, 343-4.

39 Nunn JF. Applied Respiratory Physiology. Ed 2, Butterworths; London, 1977, p 186.

40 Bain JA, Spoerel WE. Carbon dioxide output and elimination in children under anaesthesia. Can Anaesth Soc J 1977; 24: 533-9.

41 Nunn JF. Applied Respiratory Physiology. Ed 2, Butterworths; London, 1977, p 354.

42 Kain ML, Panday J, Nunn JF. The effect of intuba. tion on the deadspace during halothane anaesthesia. Br J Anaesth 1969; 41: 94-102.

43 Spoerel WE, Aitken RR, Bain JA. Spontaneous respiration with the Bain breathing circuit. Can Anaesth Soc J 1978; 25: 30-5.

44 White $D C$, Halsey $M J$. Anaesthetic apparatus. In: Gray TC, Utting JE, Nunn JF, eds. General Anaesthesia. Ed 4, London: Butterworths, 1980: 967-91.

45 Nunn JF. Potential economics of using closed circuit anesthesia. In: Aldrete JA, Lowe HJ, Virtue RW, eds. Low Flow and Closed System Anesthesia. New York: Grune \& Stratton, 1979: 109-12.

\section{Résumé}

Le système de Humphrey A.D.E. à levier unique pour des circuits anesthésiques tant dans les formes coaxiales que les formes parallèles (non coaxiales) a été récemment introduit. En principe le système offre un fonctionnement universel efficace en combinant les avantages du système Mapleson A, D et E. Une comparaison de son fonctionnement en mode $E$ chez des patients anesthésiés en respiration spontanée a été faite avec celle du circuit Magill (Mapleson A) et du circuit de Bain (Mapleson B). Le système coaxial est parallèle à levier unique A.D.E. lorsqu' employé avec des flots de gaz frais moyens de 51 $\mathrm{ml} \cdot \mathrm{kg}^{-1} \cdot \mathrm{min}^{-1} n^{\prime}$ a provoqué qu' une réinspiration minime. Sous des conditions indentiques, le flot de gaz frais moyen requis pour provoquer la réinspiration était de $71 \mathrm{ml}$. $\mathrm{kg}^{-1} \cdot \mathrm{min}^{-1}$ pour le circuit Magill et de $150 \mathrm{ml} \cdot \mathrm{kg}^{-1} \cdot \mathrm{min}^{-1}$ pour le système de Bain. En pratique, le contrôle de la pollution dans les salles d' opération était facilité avec le système A.D.E. par une réduction simultanée des fots de gaz frais et la facilité d' attache du système anti pollution d la machine. Le fonctionnement et les avantages pratiques de ce circuit sant présentés. 